\title{
Implementasi 4QC Tools Dan IOT Sebagai Pengendali Kegagalan Produk Usaha Batik Fendy, Klaten
}

\author{
Lilia Pasca Riani a,1,*, Arwan Nur Ramadhan ${ }^{\text {b,2 }}$ \\ a,b Fakultas Ekonomi, Universitas Negeri Yogyakarta \\ ${ }^{1}$ lilia.pasca.riani@uny.ac.id *; ${ }^{2}$ arwan@uny.ac.id; \\ * corresponding author
}

ARTICLE INFO

Article history

Received

Revised

Accepted

Keywords

Quality control;

Histogram;

Pareto Diagram;

p Control Chart;

Fishbone Diagram

\section{ABSTRACT}

The study was conducted to identify the types of product defects, monitor the production process, and map the causes of product defects in the Batik Fendy Klaten Business, Central Java. The analysis method is carried out in 4 stages, namely making a histogram, pareto diagram, analyzing the control map p, and mapping the cause of product defects with a fishbone diagram. Primary and secondary data analysis in the form of data on the number of production and the number of defective products from November 2018 to October 2019. The results showed that the torn cloth is a dominant type of disability with a percentage of $32 \%$ of the total product defects, depicting the control chart $p$ there are 7 out of 12 observation periods occurred processes that exceed the lower control limit, namely in November, December 2018, May, September, and October 2019 are under the lower control limit, whereas in November 2018, February, March and April 2019 are above the upper control limit, identification of the causes is found carelessness, manual method of cutting, material not according to criteria, and hot ambient temperature galvalume.

\section{PENDAHULUAN}

Kualitas menjadi prioritas utama dalam perusahaan. Kualitas merupakan hal sangat penting bagi perusahaan yang mengedepankan keunggulan kompetitif sekaligus keunggulan komparatif (Heizer, Render, \& Munson, 2017b). Kemampuan mempertahankan kualitas dapat membuat perusahaan memenangkan persaingan yang semakin ketat di era modern ini (Ross et al., 2017). Kualitas dalam hal ini mencakup berbagai aspek antara lain kualitas produk, kualitas proses produksi, dan kualitas layanan yang bertujuan untuk memberikan kepuasan tersendiri bagi konsumen (Riani, 2016; Robbi, 2017).

Mempertahankan kualitas proses produksi menjadi tantangan perusahaan. Penyelenggaraan proses produksi yang berkualitas menjadi tantangan bagi setiap pengelola di industri manufaktur, karena proses yang berkualitas dapat menekan jumlah produk cacat dan meminimalkan kerugian material sebagai akibat dari kegagalan produk (Bernik \& Zusnita, 2019; Margarette \& Pujotomo, 2016). Sehingga perlu menerapkan sistem pengendalian kualits yang mumpuni, terutama untuk proses produksi semi manual seperti pembuatan kain batik. Salah satu cara dalam pengendalian kualitas produk adalah dengan menekan produk cacat seminimal mungkin, mengidentifikasi faktor penyebab, dan melakukan tindakan perbaikan pada periode berikutnya (Purnomo, 2018).

Usaha Batik Fendy berlokasi di Desa Geblegan, Kecamatan Kalikotes, Kabupaten Klaten, Provinsi Jawa Tengah. Batik Fendy merupakan salah satu pengrajin batik di Kabupaten Klaten yang memiliki omset terus meingkat dalam 5 tahun terakhir yang dapat dilihat pada gambar 1. Fokus usaha meliputi pembuatan kain batik dan produksi baju batik dengan berbagai model. Selama proses pembuatan kain batik dilakukan secara semi manual, yaitu ada beberapa proses yang dilakukan menggunakan bantuan mesin, dan beberapa proses lain dikerjakan oleh tenaga kerja manusia. Proses produksi yang dikerjakan oleh tenaga kerja manusia cenderung lebih sering mengalami kecacatan produk dibandingkan dengan tenaga mesin. Selama ini, proses produksi Usaha Batik Fendy belum menggunakan metode yang sistematis untuk mengevaluasi dan mengendalikan proses produksi sehingga banyak kain batik tidak sesuai standar namun dapat lolos masuk ke tahap pembuatan baju/pakaian batik. 


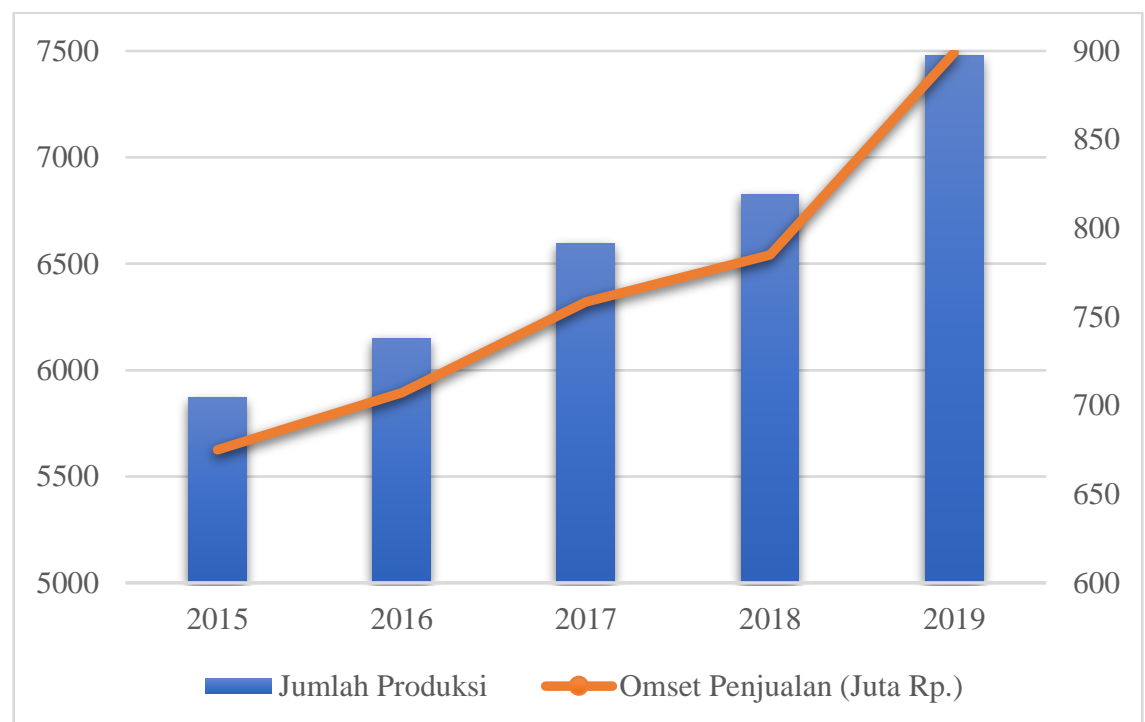

Gambar 1. Peningkatan jumlah produksi dan omset penjualan Batik Fendy

Hasil observasi menemukan hambatan dalam proses produksi. Pada observasi awal ditemukan peningkatan jumlah produksi dan omset penjualan Batik Fendy tetapi juga mengalami hambatan tersendiri dalam proses produksi. Hambatan proses produksi adalah pada kesalahan kerja karyawan. Kesalahan yang sering terjadi dalam pembuatan kain batik berpotensi menimbulkan kerugian. Kerugian terjadi karena kecacatan produk pada proses produksi. Kain batik yang mengalami kecacatan produksi tidak dapat didaur ulang atau dilakukan pengerjaan ulang sehingga harus dibuang. Penelitian ini melakukan klasifikasi jenis kecacatan pada setiap tahap proses produksi kain Batik Fendy. Klasifikasi dilakukan menggunakan peta kendali $p$ untuk memonitor proses produksi, dan mengidentifikasi faktor penyebab kecacatan produksi kain batik Usaha Batik Fendy.

\section{KAJIAN PUSTAKA}

\section{Definisi Kualitas}

Bernik \& Zusnita (2019); Heizer et al., (2017a) mengemukakan definisi mendasar dari kualitas adalah keseluruhan karakteristik yang dimiliki oleh sebuah produk atau layanan jasa yang melebihi ekspektasi peenggunanya. Semakin jauh jarak yang diciptakan antara kemampuan produk dan ekspektasi penggunakanya menyatakan bahwa produk tersebut semakin berkualitas. Sejalan dengan itu Purnomo (2018) dan Sutaryono (2020) menambahkan kualitas sebagai keunggulan fisik, sifat, dan fungsi yang dimiliki oleh sebuah produk atau jasa dalam upayanya memenuhi kebutuhan dan harapan konsumen.

Margarette \& Pujotomo (2016) menyebutkan pembeli akan membeli produk yang dirasakan cocok, karena itu produk harus disesuaikan dengan keingginan penggunanya agar pemasaran produk berhasil. Lebih lanjut dalam Heizer et al., (2017a) terdapat 8 dimensi dari kualitas, yaitu: 1) Performance, berkaitan dengan karakteristik utama suatu produk; 2) Features, keunggulan/keunikan tersendiri yang dimiliki produk; 3) Reliability, berkaitan dengan kekonsistenan; 4) Durability, berkaitan dengan daya tahan produk beroperasi; 5) Aesthetics, berkaitan dengan keindahan tampilan dan ergonomis; 6) Serviceability, kemudahan layanan perbaikan; 7) Quality of Conformance, kesesuaian dengan spesifikasi; dan 8) Perceived Quality, persepsi tentang kualitas dimata konsumen.

\section{Pengendalian Kualitas}

Menurut Margarette \& Pujotomo (2016) pengendalian kualitas merupakan suatu aktifitas untuk menjaga dan mengarahkan agar kualitas produk perusahaan dapat dipertahankan sebagaimana yang telah direncanakan. Purnomo (2018) menambahkan pengendalian kualitas harus dilakukan sebagai bentuk komitmen perusahaan, baik komitmen terhadap pelanggannnya maupun komitmen terhadap keberlangsungan usahanya.

Lebih lanjut pengendaliaan kualitas menurut Sari \& Sudiartha (2019) merupakan kegiatan sistematis dimulai dari perencanaan hingga pengawasan proses produksi yang dimulai dari bahan mentah hingga bahan tersebut berubah menjadi produk jadi agar sesuai dengan kriteria yang ditetapkan oleh perusahaan. Apabila produk tidak sesuai dengan kriteria yang ditetapkan oleh perusahaan, maka disebut dengan produk gagal / cacat. Dan apabila perusahaan mengalami proses produksi yang menghasilkan banyak produk cacat maka perlu

Lilia Pasca Riani, et al (Implementasi 4QC Tools Dan IOT Sebagai Pengendali Kegagalan...) 
dilakukan evaluasi dan dicari penyebab untuk dapat diambil tindakan sedemikian rupa agar tidak berlarut-larut dan merugikan perusahaan.

Menurut Supriyadi (2018) terdapat beberapa langkah dalam merancang sebuah system pengendalian kualitas, yakni 1) mengidentifikasi titik kritis sebagai batas toleransi yang diijinkan pada setiap prses dimana inspeksi dilakukan, 2) menetapkan jenis pengukuran yang dilakukan padda proses inspeksi yang berdasarkan variable atau atribut., 3) inspeksi dilakukan pada keseluruhan produk ataukah mengambil sampel dengan metode tertentu sebagai gambaran kondisi keseluruhan, 4) menentukan tanggung jawab dan wewenang kepada siapa yang melakukan inspeksi.

\section{Alat Bantu Pengendalian Kualitas}

Alat bantu yang sering digunakan dalam pengendalian persediaan adalah Statistical Quality Control dengan ke 7 tools / alat bantu yang dapat digunakan. Disebut Statistical karena menggunakan data statistic untuk melihat sinyal-sinyal yang mungkin timbul saat terjadi penyimpangan proses produksi. Sari \& Sudiartha (2019) menyebutkan bahwa penerapan SQC yang baik dan benar didalam perusahaan dapat meningkatkan kinerja proses produksi serta mengurangi variabilitas produk dan meningkatkan efisiensi produksi dengan mengurangi pemborosan dan pengerjaan ulang.

\section{Check Sheet}

Sebuah formulir yang digunakan oleh perusahaan saat inspeksi suatu proses. Formulir ini merupakan data real time yang diisikan langsung pada saat proses produksi sedang berlangsung. Data yang dikumpulkan biasanya terkait dengan jumlah produksi, jumlah produk cacat, dan waktu terjadinya produk cacat tersebut.

\section{Flow Chart}

Merupakan gambar visual yang berisikan tahapan-tahapan proses produksi. Dengan flow chart ini dapat diketahui dengan pasti pada tahap mana terjadi kecacatan produk untuk kemudian dapat dievaluasi proses tersebut dan ditindak lanjuti untuk mengeliminasi kecacatan produk.

\section{Diagram Pencar (Scatter Plot)}

Merupakan gambar visual yang memetakan sebaran data, biasanya untuk melihat keterhubungan antara dua / lebih variable dan melihat tren atau kecenderungan dari keterikatan dua data tersebut.

\section{Histogram}

Histogram merupakan sebuah diagram berbentuk batang / balok yang digunakan untuk membaca dan menjelaskan data dengan cepat, penyajian data dilakukan sedemikian rupa untuk melihat kecenderungan data, fluktuasi data, dan distribusi frekuensi data.

\section{Diagram Pareto}

Diagram ini merupakan lanjutan dari Histogram, digunakan untuk melihat jenis kecacatan produk yang dominan terjadi dengan prosentase kecacatan paling tinggi, sehingga peengelola dapat memfokuskan perhatian pada jenis kecacatan yang dominan tersebut untuk ditanggulangi.

\section{Diagram fishbone}

Berbentuk mirip tulang ikan sebagai penggambaran mengenai penyebab terjadinya kecacatan produk. Ujung kepala ikan merupakan jenis kecacatan dan tulang atau duri pada sirip ikan adalah penyebab-penyebabnya. Semakin detail penyebab dapat diientifikasi maka semakin rigid penggambaran duri ikannya.

\section{Peta Kendali $p$}

Peta kendali merupakan sebuah grafik yang didalamnya mencantumkan Garis tengah atau central line yang bermakna target, batas kendali atas dan batas kendali bawah yang merupakan area batas-batas pengendalian yang ditoleransi. Peta kendali $\mathrm{p}$ digunakan untuk mengidentifikasi proses secara statistika sehingga dapat diketahui proses masih berada dalam batas kendali atau diluar batas kendali. Dalam hal ini adalah kecacatan yang masih diberikan toleransi atau sudah diluar toleransi. Penentuan ambar grafik pada peta kendali $\mathrm{p}$ didasarkan pada hasil perhitungan sebagai berikut : 


$$
\begin{gathered}
\bar{p}=C L=\frac{\sum x_{i}}{n_{i}} \\
U C L=\bar{p}+3 \sqrt{\frac{\bar{p}(1-\bar{p})}{n}} \\
L C L=\bar{p}-3 \sqrt{\frac{\bar{p}(1-\bar{p})}{n}}
\end{gathered}
$$

Keterangan :

$\bar{p}=$ proporsi produk cacat dibandingkan keseluruhan produk

$C L=$ Nilai tengah

$U C L=$ Upper Control Limit (Batas Kendali Atas)

$L C L=$ Lower Control Limit (Batas Kendali Bawah)

Nominal 3 = merupakan 3 sigma, target keberhasilan mencapai 99\%

\section{Internet of Things (IoT)}

Penerapan Internet of Things (IoT) sejauh ini digunakan pada komunikasi machine to machine (M2M) di bidang sistem kendail, bidang industri, bidang manufaktur dan lainnya (Prayudha, Pranata, \& Al Hafiz, 2018). Produk berbasis Internet of Things akan mempermudah seseorang dalam mendapatkan data yang akurat dan cepat berbasis sistem cerdas (smart machine). Internet of Things (IoT) merupakan perkembangan teknologi yang menjanjikan dapat mengoptimalkan kehidupan dengan sensor sensor cerdas dan benda yang memiliki jaringan dan bekerjasama dalam internet (Ruuhwan, Rizal, \& Karyana, 2019). Internet of Things (IoT) mengacu pada koneksi berbagai perangkat yang menyerupai komputasi tertanam yang dapat terdeteksi seperti sensor pada mobil, implant pemantauan jantung, transponder biochip pada hewan ternak (Chen, Viho, Baire, Huang, \& Zha, 2013).

\section{METODE PENELITIAN}

Penelitian ini menggunakan pendekatan kuantitatif, dengan jenis penelitian deskriptif. Subyek penelitian adalah Usaha Batik Fendy yang beralamat di Desa Gemblegan, Kecamatan Kalikotes, Kabupaten Klaten, Provinsi Jawa Tengah. Teknik Pengumpulan data dilakukan dengan wawancara dengan pemilik Usaha Batik Fendy, Observasi langsung untuk memperoleh data jumlah produksi dan jumlah produk cacat. Data yang digunakan adalah data produksi dan data jumlah produk cacat Usaha Batik Fendy selama periode November 2018 - Oktober 2019.

Lingkup peenelitian ini fokus pada pengendalian kualitas produk Batik Fendy. Pengumpulan data dilakukan selama periode bulan November 2018 bingga Oktober 2019 dengan data yang dpergunakan adalah data jumlah prroduksi, dan data jumlah produk cacat selama periode peengumpulan data. Alat analisis yang dipakai adalah 4 Tools Pengendalian Kualitas, yakni Histogram, Diagram Pareto, Peta Kendali p, dan Diagram Fishbone. Desain penelitian dilakukan mengikuti alur secara berurutan dan sistematis sesuai gambar 2 berikut. 


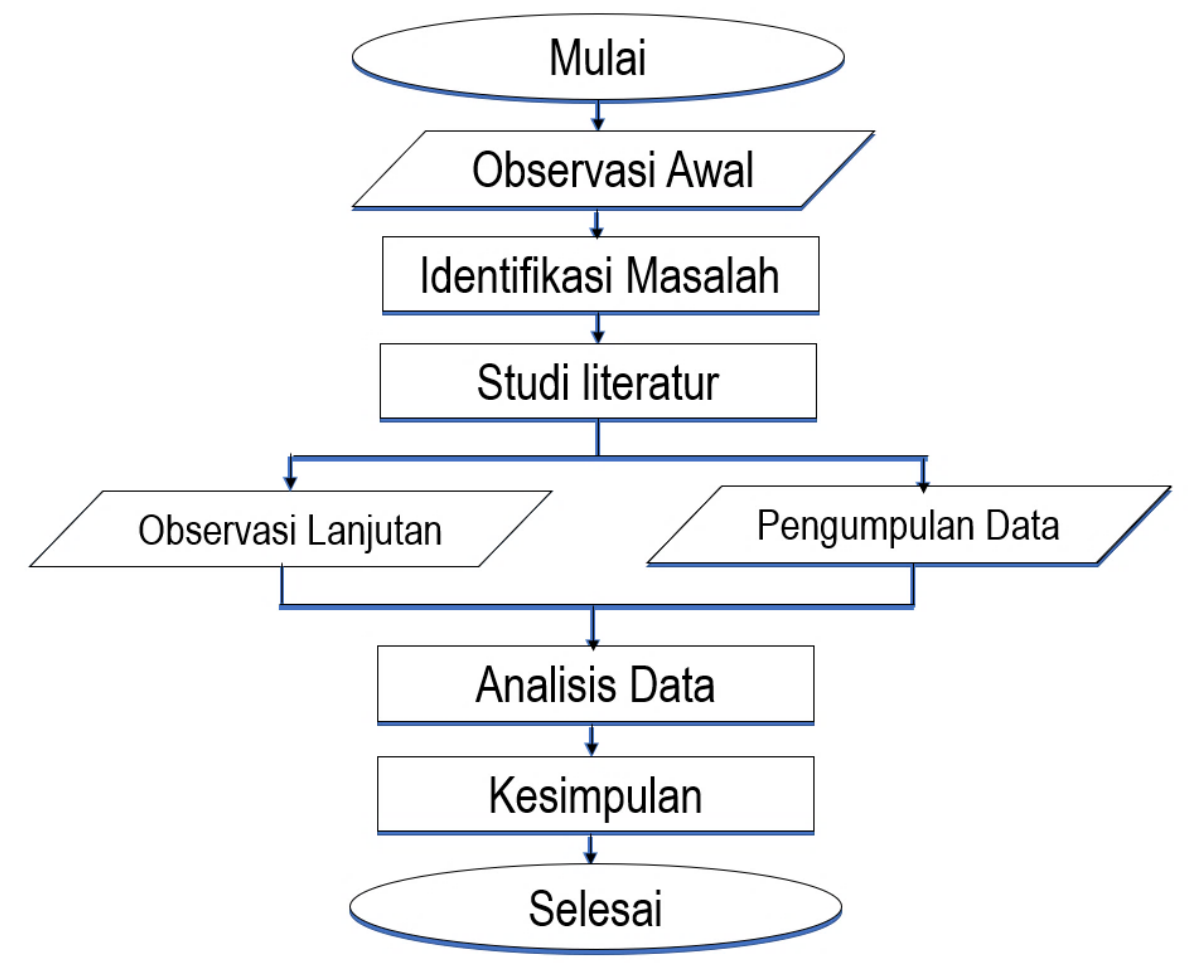

Gambar 2. Alur Penelitian

Penelitian menggunakan 5 tahapan analisis data yaitu: 1) Mengklasifikasikan jenis kecacatan dan memberi nama pada jenis kecacatan; 2) Menggambarkan grafik histogram untuk menganalisis jenis kecacatan dan jumlah produk cacat; 3) Membuat diagram Pareto untuk menganalisis jenis kecacatan yang dominan; 4) Memetakan proporsi kecacatan pada peta kendali p, dalam membuat peta kendali p; dan 5) Memetakan penyebab keecacatan yang dominan dari berbagai aspek dengan diagram fishbone

Peta kendali merupakan sebuah grafik yang mencantumkan garis tengah/central line dan bermakna target, batas kendali atas, dan batas kendali bawah yang merupakan area batas-batas pengendalian yang ditoleransi. Peta kendali p digunakan untuk mengidentifikasi proses secara statistika sehingga dapat diketahui proses masih berada dalam batas kendali atau diluar batas kendali. Penentuan grafik pada peta kendali p didasarkan pada hasil perhitungan sebagai berikut:

\section{Keterangan :}

$$
\begin{aligned}
& \bar{p}=C L=\frac{\sum x_{i}}{n_{i}} \\
& U C L=\bar{p}+3 \sqrt{\frac{\bar{p}(1-\bar{p})}{n}} \\
& L C L=\bar{p}-3 \sqrt{\frac{\bar{p}(1-\bar{p})}{n}}
\end{aligned}
$$

$\bar{p}=$ proporsi produk cacat dibandingkan keseluruhan produk

$\mathrm{CL}=$ Nilai tengah

$U C L=$ Upper Control Limit (Batas Kendali Atas)

$L C L=$ Lower Control Limit (Batas Kendali Bawah)

Nominal 3 = merupakan 3 sigma, target keberhasilan mencapai 99\%

\section{HASIL PENELITIAN}

\section{Pengumpulan Data dan Analisis Data}

\section{Pengumpulan data}

a. Data Produksi Batik Fendy 
Tabel 1 menjelaskan data produksi Batik Fendy selama periode November 2018 hingga Oktober 2019. Diketahui total produksi sebanyak 80.138 potong kain batik. Kain batik yang diproduksi oleh Batik Fendy terdiri dari 2 jenis, yakni kain bating cap dan kain batik tulis. Berikut adalah grafik tren jumlah produksi kain batik Fendy.

Tabel 1. Data Produksi Batik Fendy

\begin{tabular}{lcllc}
\multicolumn{1}{c}{ Periode } & Total Produksi (potong) & & Periode & Total Produksi (potong) \\
\hline November & 6680 & Mei & 6812 \\
\hline Desember & 6482 & Juni & 6710 \\
\hline Januari & 6434 & Juli & 7003 \\
\hline Februari & 6644 & Agustus & 6774 \\
\hline Maret & 6415 & September & 6753 \\
\hline April & 6719 & Oktober & 6712 \\
\hline & Total Produksi & & $\mathbf{8 0 1 3 8}$
\end{tabular}

Sumber : data sekunder diolah, 2020

Dilihat dalam tabel 1 tentang data produksi Batik Fendy, jumlah produksi Batik Fendy cendetung mengalami peningkatan setiap bulan, meskipun sejak bulan Juli 2019 hingga Oktober 2019 secara konsisten terus mengalami penurunan. Hasil wawancara dengan pemilik usaha Batik Fendy, fluktuasi produksi disebabkan karena intuisi dari pemilik bahwa setelah mengalami puncak produksi pada bulan Juli, penjualan pada bulan Agustus mengalami penurunan, sehingga produksi untuk bulan Agustus dikurangi untuk menghabiskan persediaan kain batik yang masih belum terjual.

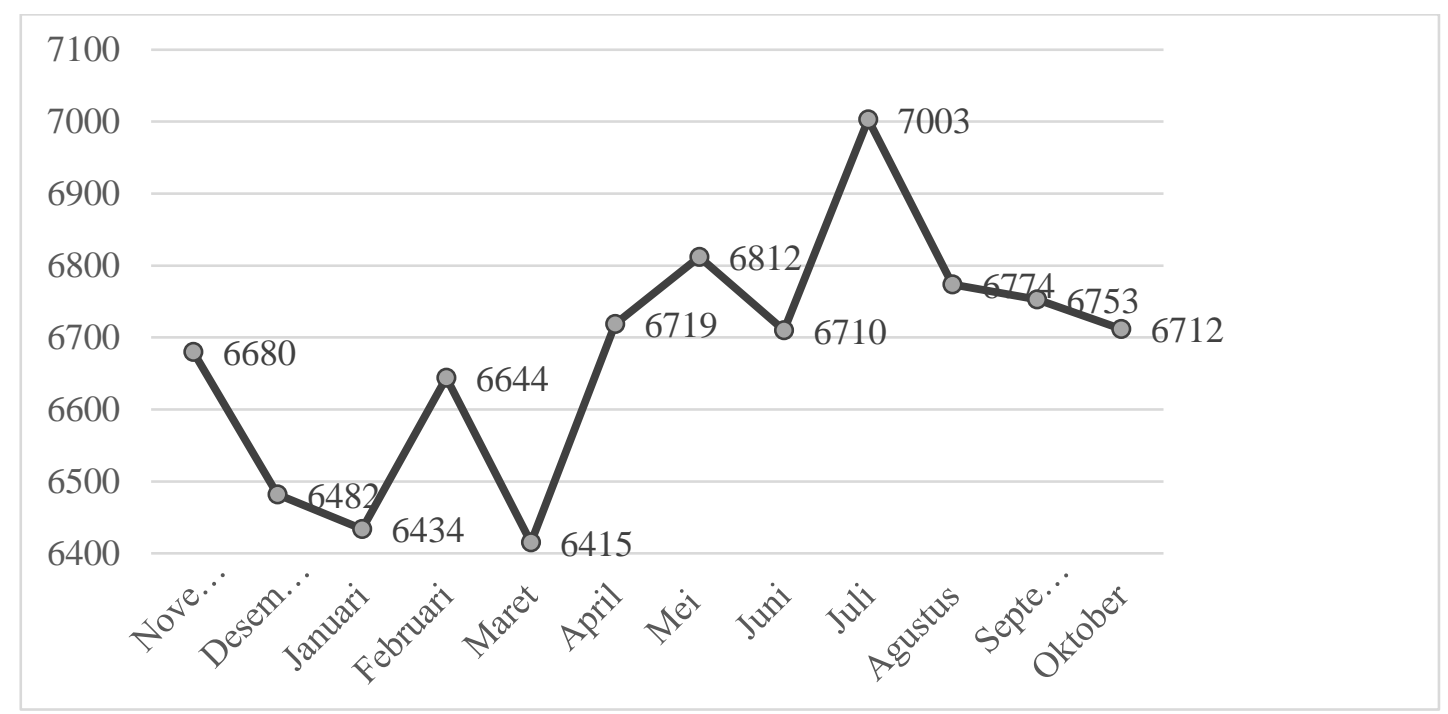

Gambar 3. Tren jumlah produksi Batik Fandy bulan November 2018 - Oktober 2019

b. Data Produk Cacat Batik Fendy

Tabel 2 menyajikan data produk cacat pada Usaha Batik Fendy periode November 2018 hingga Oktober 2019 dengan total produk cacat sebanyak 26.473 potong kain batik. Apabila dibandingkan dengan jumlah produksi secara keseluruhan maka persentase produk cacat sebesar $32 \%$.

Tabel 2. Data Produk Cacat Batik Fendy bulan November 2018 - Oktober 2019

\begin{tabular}{lccc}
\hline \multicolumn{1}{c}{ Periode } & Jumlah Produk Cacat & Periode & Jumlah Produk Cacat \\
\hline November & 2332 & Mei & 2098 \\
\hline Desember & 1967 & Juni & 2141 \\
\hline Januari & 1989 & Juli & 2402 \\
\hline Februari & 2301 & Agustus & 2313 \\
\hline Maret & 2326 & September & 1830 \\
\hline April & 2493 & Oktober & 1976 \\
\hline & Total kecacatan & & $\mathbf{2 6 4 7 3}$ \\
\hline
\end{tabular}

Sumber : data sekunder diolah, 2020

Lilia Pasca Riani, et al (Implementasi 4QC Tools Dan IOT Sebagai Pengendali Kegagalan...) 


\section{Analisis Data}

a. Identifikasi jenis kecacatan produk

Berdasarkan hasil wawancara dan observasi, diperoleh hasil bahwa terdapat 6 jenis kecacatan produk yang sering terjadi pada proses produksi kain batik Fendy, yakni warna pudar/luntur (WP/L), kain menyusut (KM), warna belang (WB), kain sobek (KS), terdapat kotoraan (TK), dan corak meleset dari pola kain (CMPL). Berikut adalah jumlah kecacatan dari masing-masing jenis kecacatan produk yang disajikan dalam gambar 3.

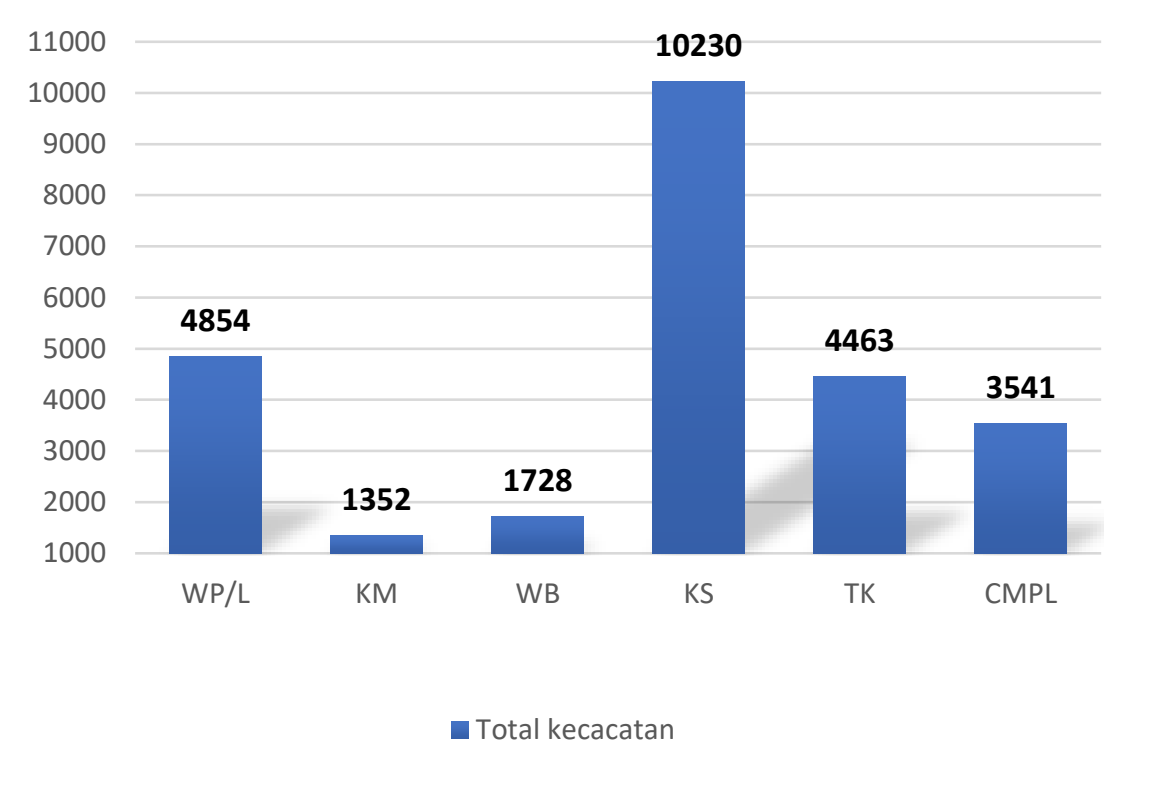

Gambar 4. Histogram Jumlah Kecacatan berdasarkan jenis kecacatan produk batik Fendy

Dilihat pada gambar 4 diketahui bahwa jenis kecacatan kain sobek merupakan jenis kecacatan yang paling sering terjadi, yakni sebanyak 10.230 potong dengan persentase $39,1 \%$ dari seluruh jenis kecacatan dan corak meleset dari pola kain merupakan jenis kecacatan paling sering berikutnya, sebanyak 4854 potong atau sebesar $18,5 \%$ dari semua jenis kecacatan.

b. Identifikasi jenis kecacatan produk yang dominan

Pada pengamatan yang dilakukan, kain sobek meerupakan jenis kecacatan yang paling sering terjadi. Pada table 3 diketahui jenis kecacatan ditinjau dari frekuensinya adalah kain sobek, warna pudar/luntur, terdapat kotoran, corak meleset dari pola kain, warna belang, dan kain menyusut.

Tabel 3. Persentase kumulatif kecacatan produk

\begin{tabular}{lccc}
\hline \multicolumn{1}{c}{ Jenis Kecacatan } & $\begin{array}{c}\text { Jumlah Produk } \\
\text { Cacat }\end{array}$ & $\begin{array}{c}\text { Prosentase } \\
\text { kecacatan }\end{array}$ & Kumulatif \\
\hline Kain sobek & 10230 & $39 \%$ & $39 \%$ \\
\hline Warna pudar/luntur & 4854 & $19 \%$ & $58 \%$ \\
\hline Terdapat kotoran & 4463 & $17 \%$ & $75 \%$ \\
\hline Corak meleset dari pola kain & 3541 & $14 \%$ & $88 \%$ \\
\hline Warna belang & 1728 & $7 \%$ & $95 \%$ \\
\hline Kain menyusut & 1352 & $5 \%$ & $100 \%$ \\
\hline Jumlah & $\mathbf{2 6 1 6 8}$ & $\mathbf{1 0 0 \%}$ & \\
\hline
\end{tabular}

Sumber : Data Sekunder diolah, 2020.

Pada gambar 4 diketahui bahwa terdapat 3 jenis kecacatan yang dominan dengan persentase mencapai $75 \%$ dari keseluruhan jumlah kecacatan yang terjadi, yakni kain sobek, warna pudar/luntur, dan terdapat kotoran. Hasil analisis pada Diagram Pareto selnjutnya digunakan untuk mengidentifikasi penyebab terjadinya kecacatan tersebut. 


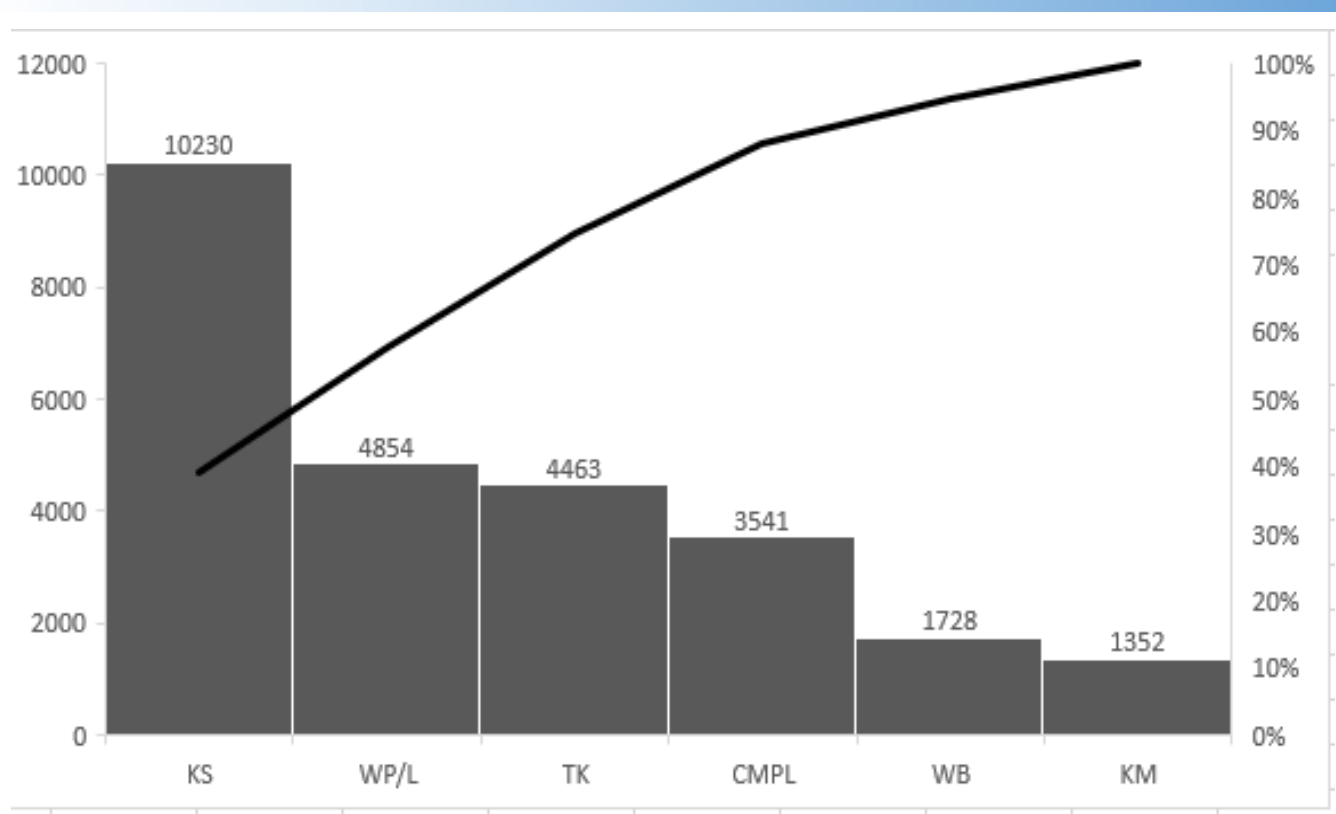

Gambar 4. Diagram Pareto jumlah dan prosentase kecacatan produk Batik Fendy

c. Memonitor proses produksi sesuai batas kendali

Tabel 4 merupakan hasil perhitungan proporsi kecacatan jenis kain sobek terhadap keseluruhan jumlah produksi Batik Fendy. Perhitungan proporsi merupakan data yang digunakan pada langkah berikutnya yaitu membuat peta kendali $\mathrm{p}$. Peta kendali $\mathrm{p}$ digunakan untuk memetakan apakah proporsi kecacatan kain sobek masih berada dalam batas kendali atau tidak dengan jumlah produksi yang tidak sama pada setiap periodenya.

Tabel 4. Perhitungan Proporsi Kecacatan terhadap Jumlah Produksi

\begin{tabular}{lccc}
\hline \multicolumn{1}{c}{ Periode } & $\begin{array}{c}\text { Total Produksi } \\
\text { (potong) }\end{array}$ & Total kecacatan & $\begin{array}{c}\text { Proporsi Kecacatan terhadap Total } \\
\text { Produksi }\end{array}$ \\
\hline November & 6680 & 2332 & 0,349 \\
\hline Desember & 6482 & 1967 & 0,303 \\
\hline Januari & 6434 & 1989 & 0,309 \\
\hline Februari & 6644 & 2301 & 0,346 \\
\hline Maret & 6415 & 2326 & 0,363 \\
\hline April & 6719 & 2493 & 0,371 \\
\hline Mei & 6812 & 2098 & 0,308 \\
\hline Juni & 6710 & 2141 & 0,319 \\
\hline Juli & 7003 & 2402 & 0,343 \\
\hline Agustus & 6774 & 2313 & 0,341 \\
\hline September & 6753 & 1830 & 0,271 \\
\hline Oktober & 6712 & 1976 & 0,294 \\
\hline Jumlah & $\mathbf{8 0 1 3 8}$ & 26168 & \\
\hline
\end{tabular}

Sumber : Data sekunder diolah, 2020

Peta kendali $\mathrm{p}$ memiliki beberapa elemen yang harus dihitung lebih dahulu, antara lain menghitung Central Line, Standar Deviasi, Upper Limit Control (UCL), dan Lower Limit Control (LCL). Berikut hasil perhitungan yang disajikan secara perhitungan manual

$$
\begin{gathered}
\bar{p}=C L=\frac{\sum x_{i}}{n_{i}}=\frac{10230}{80138}=0,327 \\
\text { St.dev.p }=\sqrt{\frac{\bar{p}(1-\bar{p})}{n}}=\sqrt{\frac{0,327(1-0,327)}{2332}}
\end{gathered}
$$




$$
\begin{gathered}
=\sqrt{\frac{0,206}{2332}=0,006} \\
U C L=\bar{p}+3 \cdot \sqrt{\frac{\bar{p}(1-\bar{p})}{n}}=0,327+3.0,006=0,344 \\
L C L=\bar{p}-3 \cdot \sqrt{\frac{\bar{p}(1-\bar{p})}{n}}=0,327-3.0,006=0,309
\end{gathered}
$$

Hasil perhitungan CL, UCL, dan LCL digunakan untuk menggambarkan peta kendali p pada langkah selanjutnya.

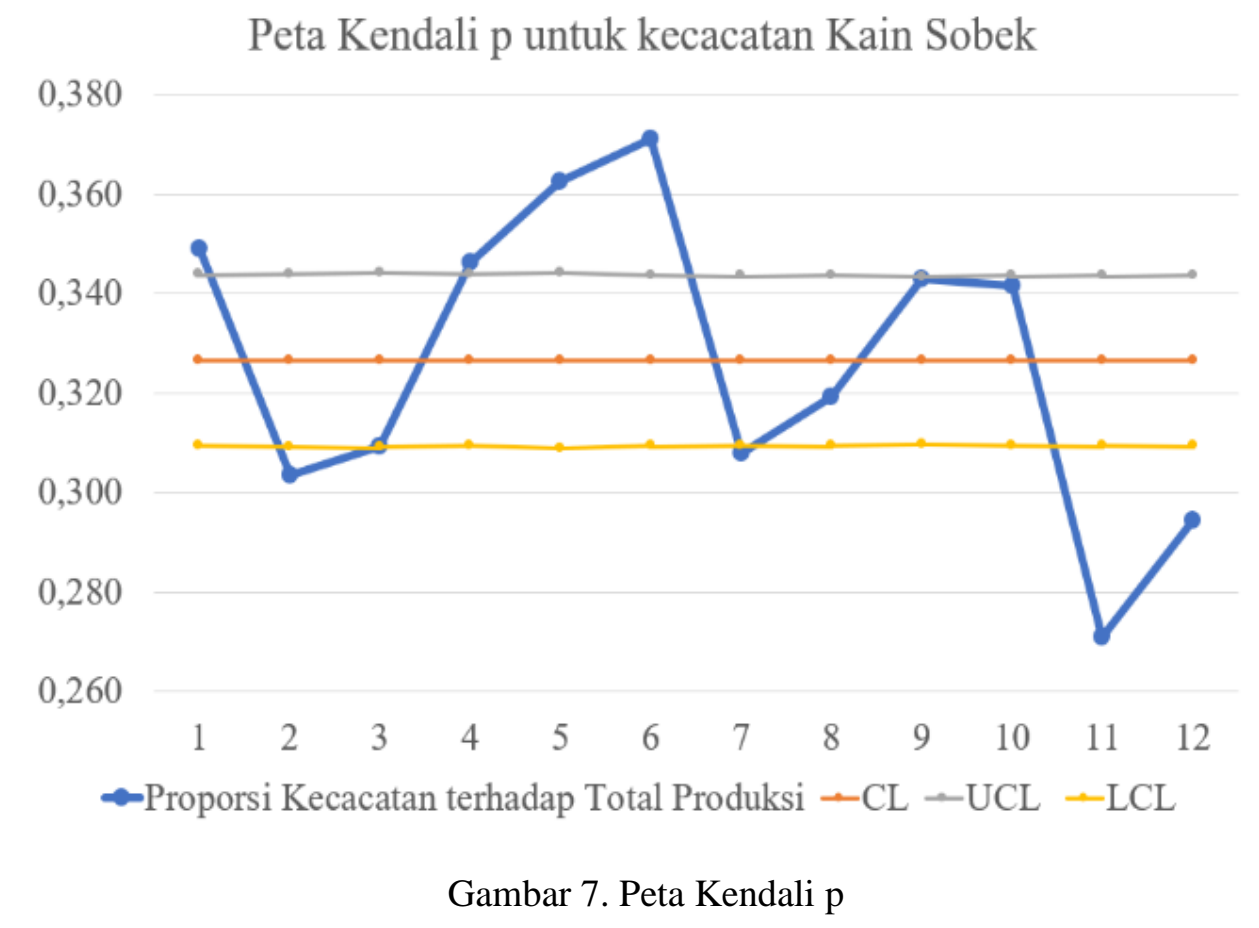

Peta kendali $\mathrm{p}$ digunakan untuk memetakan posisi proses produksi Batik Fendy apakah terdapat prroses yang melewati batas kendali ataukah tidak. Seperti tergambar pada gambar 7 terdapat beberapa periode yang melewati batas kendali. Pada bulan November, Desember 2018, Mei, September, dan Oktober 2019 berada di bawah batas kendali bawah, sedangkan pada bulan November 2018, Februari, Maret dan April 2019 berada di atas batas kendali atas. Sehingga secara keseluruan ada 7 bulan selama periode pengamatan 12 bulan berada diluar batas kendali. Hal ini harus menjadi perhatian khusus bagi pengelola Usaha Batik Fendy karena proses produksi yang menyeebabkan kecacatan kain sobek terjadi pada 6 bulan dalam satu tahun.

d. Mengidentifikasi penyebab kecacatan produk dengan Diagram Fishbone

Diagram Fishbone dikenal juga dengan istilah Diagram tulang ikan atau diagram sebab-akibat. Diagram ini digunakan untuk mengidentifikasi secara rinci hal-hal yang menjadi penyebab terjadinya kecacatan produk. Dalam hal ini adalah Kain sobek. Berikut adalah gambar Diagram Fishbone untuk mengidentifikasi penyebab terjadinya kecacatan kain sobek pada Usaha Batik Fendy: 


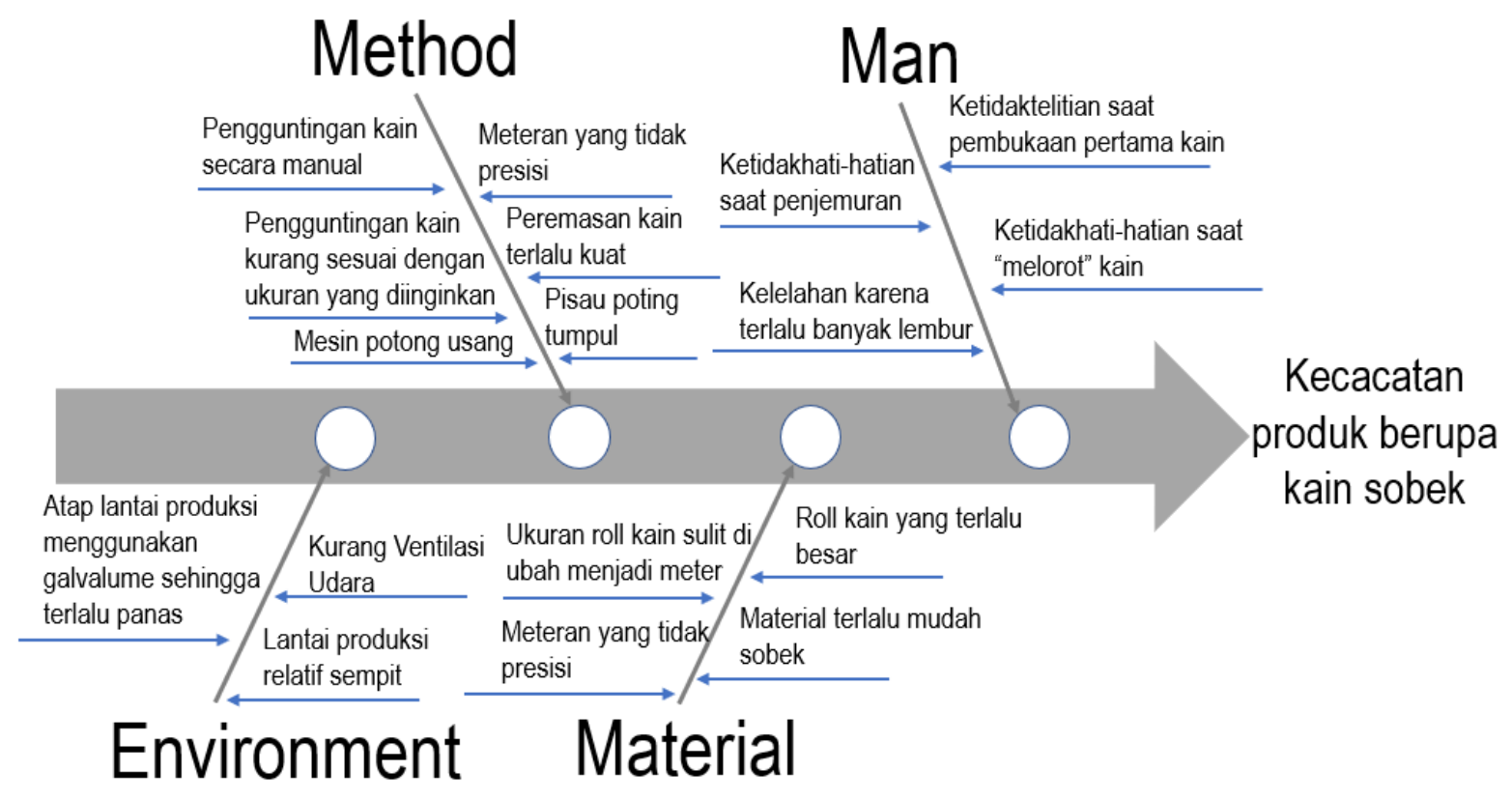

Gambar 8. Diagram Sebab-Akibat

Hasil wawancara dengan Pengelola Usaha Batik Fendy meemperoleh beberapa jawaban yang berkaitan erat dengan tujuan penelitian mengidentifikasi penyebab kecacatan produk Batik Fendy, dalam hal ini kecacatan jenis Kain Sobek. Terdapat 4 aspek utama penyebab terjadinya kain sobek, yaitu aspek tenaga kerja, metode kerja, bahan baku, dan lingkungan kerja.

1. Tenaga kerja, beberapa kali tenaga kerja mengalami kelelahan dalam bekerja karena terlalu sering lembur, menyebabkan ketidaktelitian saat membuka roll kain pertama kali, pengguntingan kain yang tidak sempurna, ketidakhati-hatian saat "melorot"kain, dan ketidakhati-hatian saat penjemuran.

2. Method, penggunaan alat bantu yang tidak presisi meenyebabkan sering terjadi sobek pada kain, seperti gunting yang tumpul, alat potong yang using dan kurang perawatan, posisi duduk yang salah sehingga meteran kain tidak presisi, proses peremasan kain yang terlalu kuat, dan pengguntingan kain yang tidak lurus serat kain menyebabkan kain sobek dan tidak dapat diulang pengerjaannya.

3. Material, bahan baku merupakan hal yang krusial sebagai pokok pengolahan menjadi bahan jadi. Pengelola Batik Fendy membeli kain primisima dari Solo dan Bandung sebagai bahan bakunya dan masih menggunakan cara manual untuk menilai apakah kain tersebut sesuai dengan kriteria yang diinginkan atau tidak. Roll material yang besar meenyebabkan kesulitan dalam memotong sehingga sering kali kain menjadi sobek.

4. Environment, lingkungan kerja yang panas dan kurangnya ventilasi udara membuat pekerja kurang nyaman dan proses pengeringan kain menjadi tidak sempurna sehingga mudah sobek.

\section{PEMBAHASAN}

Bernik \& Zusnita (2019); Heizer et al., (2017a) mengemukakan definisi mendasar dari kualitas adalah keseluruhan karakteristik yang dimiliki oleh sebuah produk atau layanan jasa yang melebihi ekspektasi peenggunanya. Semakin jauh jarak yang diciptakan antara kemampuan produk dan ekspektasi penggunakanya menyatakan bahwa produk tersebut semakin berkualitas. Sejalan dengan itu Purnomo (2018) dan Sutaryono (2020) menambahkan kualitas sebagai keunggulan fisik, sifat, dan fungsi yang dimiliki oleh sebuah produk atau jasa dalam upayanya memenuhi kebutuhan dan harapan konsumen.

Seperti halnya yang dilakukan oleh Usaha Batik Fendy, pengelola usaha ini berusaha sedemikian rupa untuk menyediakan produk Kain Batik dan Pakaian Batik berbagai motif dan tipe. Beberapa kali juga mendapatkan pesanan untuk memproduksi sesuai dengan motif yang sudah disediakan oleh konsumen yang umumnya dari instansi atau Lembaga tertentu dalam jumlah besar untuk segaram kerja sehingga kualitas produk meenjadi hal yang utama agar tidak meengecewakan konsumen. Oleh karena itu diperlukan sebuah sistem pengendalian kualitas yang mumpuni agar tidak banyak menghasilkan produk cacat yang merugikan perusahaan. 
Menurut Margarette \& Pujotomo (2016) pengendalian kualitas merupakan suatu aktivitas untuk menjaga dan mengarahkan agar kualitas produk perusahaan dapat dipertahankan sebagaimana yang telah direncanakan. Purnomo (2018) menambahkan pengendalian kualitas harus dilakukan sebagai bentuk komitmen perusahaan, baik komitmen terhadap pelanggannnya maupun komitmen terhadap keberlangsungan usahanya. Lebih lanjut pengendaliaan kualitas menurut Sari \& Sudiartha (2019) merupakan kegiatan sistematis dimulai dari perencanaan hingga pengawasan proses produksi yang dimulai dari bahan mentah hingga bahan tersebut berubah menjadi produk jadi agar sesuai dengan kriteria yang ditetapkan oleh perusahaan. Apabila produk tidak sesuai dengan kriteria yang ditetapkan oleh perusahaan, maka disebut dengan produk gagal/cacat. Jik perusahaan melakukan proses produksi yang menghasilkan banyak produk cacat maka perlu dilakukan evaluasi dan dicari penyebab untuk dapat diambil tindakan sedemikian rupa agar tidak berlarut-larut dan merugikan perusahaan.

Menurut Supriyadi (2018) terdapat beberapa langkah dalam merancang sebuah sistem pengendalian kualitas, yakni: 1) mengidentifikasi titik kritis sebagai batas toleransi yang diizinkan pada setiap proses dimana inspeksi dilakukan; 2) menetapkan jenis pengukuran yang dilakukan pada proses inspeksi berdasarkan variabel atau atribut; 3 ) inspeksi dilakukan pada keseluruhan produk atau mengambil sampel dengan metode tertentu sebagai gambaran kondisi keseluruhan; 4) menentukan tanggung jawab dan wewenang kepada siapa yang melakukan inspeksi.

Hasil wawancara menunjukkan pengendalian kualitas produk yang dilakukan oleh Usaha Batik Fendy selama ini masih belum dilakukan secara sistematis dalam arti belum menggunakan alat bantu yang tepat sehingga beberapa permasalahan kunci justru luput dari perhatian dan sulit dimitigasi. Oleh karena itu, penelitian ini mencoba memberikan solusi yang tepat agar tidak lagi terjadi banyak produk cacat yang tidak dapat diulang pengerjakaannya dan menimbulkan kerugian.

Berdasarkan hasil observasi terdapat 6 jenis kecacatan yang terjadi selama prroses produksi kain batik pada Usaha Batik Fendy, Klaten, yakni kain sobek, warna pudar/luntur, terdapat kotoran, warna belang, corak meleset dari pola kain, dan kain menyusut. Diketahui persentase masing-masing sebesar 39\% untuk cacat kain sobek, $19 \%$ untuk cacat warna pudar/luntur, dan $17 \%$ terdapat kotoran sebagai jenis kecacatan paling tinggi hingga $75 \%$ dari keseluruhan cacat produk yang terjadi selama periode observasi. Kajian menggunakan bantuan/tools diagram Pareto, dapat memberikan solusi bagi pengelola Usaha Batik Fendy untuk fokus memitigasi 3 jenis kecacatan yang paling dominan karena dengan mengendalikan ke 3 jenis keecacatan teersebut, yakni kain sobek, warna pudar/luntur, dan terdapat kotoran maka $75 \%$ kecacatan produk dapat diminimalisir dan sisanya tinggal jenis kecacatan minor saja.

Pada analisis menggunakan tools peta kendali p, didapatkan sebanyak 7 periode dari total 12 periode peengamatan terjadi proporsi kecacatan produk diluar batas kendali atau out of control. Hal ini harus menjadi perhatian khusus bagi pengelola Usaha Batik Fendy karena dengan sering terjadi proses yang diluar batas kendali menyebabkan kualitass produk Batik Fendy belum terjamin karena terlalu banyak produk yang cacat. Pada pemetaan dengan tools diagram sebab-akibat dapat diidentifikasi bahwa ada 4 aspek utama yang menyebabkan sering terjadinya kecacatan kain sobek, yakni: 1) aspek tenaga kerja, 2) aspek metode kerja, 3) aspek bahan baku, dan 4) aspek lingkungan kerja. Oleh karena itu, pemilik usaha batik mulai memikirkan orientasi produksi berbasis teknologi. Industri 4.0 merupakan fase baru dalam revolusi industri pada abad ini yang berfokus pada interkonektivitas, machine learning dan real time data. Kecacatan produksi dapat diminimalisir dengan machine learning. Produksi lebih banyak dikerjakan oleh mesin. Mesin produksi dapat dilengkapi dengan kecerdasan buatan agar mampu belajar dari kesalahan.

Penggunaan teknologi menjadi salah satu alternatif dalam pengendalian proses produksi. Aplikasi nanoteknologi di industri batik dapat dilakukan dengan pelapisan nanopartikel pada kain sebelum maupun setelah diproses batik dengan metode pad-dry-cure (Eskani, Haerudin, Setiawan, Lestari, \& Astuti, 2019). Pengaplikasian nanoteknologi pada produksi batik dapat meminimalisir cacat produksi, menekan harga produksi, dan ramah lingkungan. Penggunaan nano teknologi bisa menjadi solusi permasalahan warna pudar/luntur, warna belang, dan corak meleset dari pola kain. Selain itu, kendala suhu udara panas pada ruangan produksi ditambah kipas yang ditanam chip mikrokontroller berbasis IoT sehingga suhu udara dapat dikontrol dan putaran kipas dapat diatur dari jarak jauh. Teknologi tersebut dapat menghemat biaya operasional namun juga dapat meningkatkan produktivitas pekerja karena pekerja merasa nyaman berada di dalam ruangan. Selain itu, fungsi pengawasan juga dapat dilakukan dengan memasang CCTV berbasis IoT pada setiap ruang yang digunakan untuk proses produksi. Pada ruang inspeksi juga dapat dipasang camera agar

Lilia Pasca Riani, et al (Implementasi 4QC Tools Dan IOT Sebagai Pengendali Kegagalan...) 
pemilik usaha dapat melakukan pengamatan secara realtime. Pemanfaatan IoT akan dapat memperkecil resiko kecacatan dan meningkatkan kualitas produksi dari produk kain Batik Fendy.

\section{KESIMPULAN}

Hasil penelitian ini mengungkap bahwa kain sobek merupakan jenis kecacatan produk yang paling dominan dengan persentase $32 \%$ dari keseluruhan kecacatan produk yang terjadi selama periode November 2018 hingga Oktober 2019. Sebanyak 75\% kecacatan produk berasal dari 3 jenis kecacatan, yakni kain sobek, warna pudar/luntur, dan terdapat kotoran. Diketahui pada 12 periode observasi terdapat 7 periode berada diluar batas kendali yakni pada bulan November, Desember 2018, Mei, September, dan Oktober 2019 berada di bawah batas kendali bawah, sedangkan pada bulan November 2018, Februari, Maret dan April 2019 berada di atas batas kendali atas.

Identifikasi dengan diagram sebab-akibat menghasilkan 4 aspek utama penyebab terjadinya kecacatan produk, yakni tenaga kerja, metode kerja, bahan baku, dan lingkungan kerja. Oleh karena itu, bagi Pengelola Usaha Batik Fendy, hendaknya fokus untuk memitigasi pada 3 jenis kecacatan dominan, yakni kain sobek, warna pudar/luntur, dan terdapat kotoran. Hasil analisis dengan diagram sebab-akibat menemukan permasalahan kunci yaitu pada aspek tenaga kerja, Pengelola harus lebih memberikan motivasi agar ketelitian dalam memotong dan kehati-hatian dalam memeran dan menjemur kain lebih ditingkatkan. Pada aspek metode kerja, gunting atau alat potong harus selalu dilakukan perawatan agar tidak using/tumpul sehingga menyulitkan dalam memotong secara tepat. Dari aspek bahan baku, kualitas bahan baku harus diinspeksi secara ketat terutama untuk bahan baku yang dibeli dari supplier sekali tempo saat ada pesanan banyak. Dari aspek lingkungan kerja sebaiknya dilakukan pembenahan tata letak fasilitasnya agar tidak terlalu sempit, pembenahan pada atap dan menambahkan ventilasi udara agar tidak terlalu panas dan pengap, penggunaan teknologi IoT untuk melakukan control, monitoring, dan inspeksi diperlukan agar dapat menekan resiko kecacatan dan meningkatkan kualitas produksi.

Saran bagi penelitian selanjutnya. Metode dalam sistem pengendalian kualitas sangat beragam, menjadi saran bagi peneliti selanjutnya untuk menerapkan metode lain seperti Kaizen, dan Sixth Sigma dalam sistem pengendalian kualitas produk. Selain itu, diperlukan penelitian rancang bangun pengembangan teknologi untuk melakukan control, monitoring, dan inspeksi pada proses dan hasil produksi pada industry konveksi.

\section{DAFTAR PUSTAKA}

[1]. Bernik, M., \& Zusnita, W. O. (2019). METODA PENGENDALIAN KUALITAS UNTUK UMKM. Dharmakarya. https://doi.org/10.24198/dharmakarya.v7i4.14943

[2]. Chen, N., Viho, C., Baire, A., Huang, X., \& Zha, J. (2013). Ensuring Interoperability for the Internet of Things: Experience with CoAP Protocol Testing. Automatika - Journal for Control, Measurement, Electronics, Computing and Communications. https://doi.org/10.7305/automatika.54-4.418

[3]. Eskani, I. N., Haerudin, A., Setiawan, J., Lestari, D. W., \& Astuti, W. (2019). Batik Fungsional Sebagai Salah Satu Strategi Pengembangan Industri Batik Dalam Memasuki Era Industri 4.0. Prosiding Seminar Nasional Industri Kerajinan Dan Batik 2019, 1-12. Retrieved from https://proceeding.batik.go.id/index.php/SNBK/article/view/17/14

[4]. Heizer, J., Render, B., \& Munson, C. (2017a). Principles of Operations Management; Sustainability and Suply Chain Management. In Principles of Operations Management.

[5]. Heizer, J., Render, B., \& Munson, C. (2017b). Twelfth Edition Operations Management. In Operations Management.

[6]. Margarette, A., \& Pujotomo, D. (2016). Analisis Pengendalian Kualitas Proses Produksi Kain Batik Menggunakan Metode Statistical Process Control (Spc). Universitas Diponegoro.

[7]. Prayudha, J., Pranata, A., \& Al Hafiz, A. (2018). Implementasi Metode Fuzzy Logic Untuk Sistem Pengukuran Kualitas Udara Di Kota Medan Berbasis Internet of Things (Iot). Jurteksi, 4(2), 141-148. https://doi.org/10.33330/jurteksi.v4i2.57

[8]. Purnomo, H. (2018). Analisis Pengendalian Produk Cacat dengan Metode Four Quality Control (4QC) Tools. Akademika.

[9]. Riani, L. P. (Universitas N. P. K. (2016). Analisis Pengendalian Kualitas Produk Tahu Putih (Studi Kasus Pada Home Industri Tahu Kasih Di Kabupaten Trenggalek ). Jurnal Akademika.

[10]. Robbi, F. R. (n.d.). Analisis Pengendalian Kualitas dengan Menggunakan Metode Statistical Quality Control untuk Meminimumkan Jumlah Produk Cacat Kain Batik Cap pada Kareumbi Gallery Batik \&

Lilia Pasca Riani, et al (Implementasi 4QC Tools Dan IOT Sebagai Pengendali Kegagalan...) 
Bordir Subang Analysis of Quality Control By Using Statistical Quality Control Method . 1104-1110.

[11]. Ross, Westerfield, Jordan, Zhao, Y., Meng, X., Wang, S., ... Prince, J. (2017). Opeations Management 12th edition. In Corporate finance. https://doi.org/10.1017/CBO9781107415324.004

[12]. Ruuhwan, Rizal, R., \& Karyana, I. (2019). Sistem Kendali dan Monitoring pada Smart Home Berbasis Internet of Things (IoT). Innovation in Research of Informatics (INNOVATICS), 2(October), 43-50. Retrieved from http://jurnal.unsil.ac.id/index.php/innovatics/article/view/877/660

[13]. Sari, I. G. A. A. H., \& Sudiartha, G. M. (2019). Pengendalian Kualitas Proses Produksi Kopi Arabika Pada Ud. Cipta Lestari Di Desa Pujungan. E-Jurnal Manajemen Universitas Udayana, 8(4), 2495. https://doi.org/10.24843/ejmunud.2019.v08.i04.p22

[14]. Supriyadi, E. (2018). Analisis Pengendalian Kualitas Produk dengan Statistical Proses Control (SPC) di Pt. Surya Toto Indonesia, Tbk. Jitmi, 1(1), 63-73.

[15]. Sutaryono, A. (2020). Usulan Peningkatan Kualitas Kain Batik Semi Tulis menggunakan Metode Six Sigma. Jurnal Teknik Industri: Jurnal Hasil Penelitian Dan Karya Ilmiah Dalam Bidang Teknik Industri, 5(1), 48. https://doi.org/10.24014/jti.v5i1.6765

\section{PROFIL SINGKAT}

Lilia Pasca Riani. Lahir di Kediri, 18 April 1985, lulus pada program Doktor Pendidikan Ekonomi di Universitas Negeri Malang pada tahun 2016, saat ini aktif mengajar sebagai dosen PNS di Jurusan Pendidikan Ekonomi, Universitas Negeri Yogyakarta. Bidang keahlian meliputi Ekonomika Operasional, Manajemen Produksi, Manajemen Rantai Pasok.

Arwan Nur Ramadhan. Lahir di Sumba Barat, 21 April 1989, Lulus pada program magister Pendidikan Teknologi dan Kejuruan di Pascasarjana Universias Negeri Yogyakarta pada tahun 2015. Saat ini aktif mengajar di Jurusan Pendidikan Administrasi, Fakultas Ekonomi, Universitas Negeri Yogyakarta. Bidang keahlian teknologi informasi dan komunikasi. 